\title{
Instrumental Stakeholder Theory in Turbulent Environments: An Empirical Testing using Political and Social Donations
}

\author{
Rosilene Marcon ${ }^{\dagger}$ \\ University of Vale do Itajaí - UNIVALI \\ Rodrigo Bandeira de Mello ${ }^{¥}$ \\ University of Vale do Itajaí - UNIVALI \\ Anete Alberton ${ }^{\Psi}$ \\ University of Vale do Itajaí - UNIVALI
}

\begin{abstract}
In this paper we empirically tested the instrumental stakeholder theory using firm donation to government and to community as proxy for stakeholder relationship intensity. Two models were applied to a sample of 339 publicly traded firms in Brazil using different performance indicators. In the first model, a multiple regression model estimated the effects of establishing political and social stakeholder relations on firm performance, by comparing donating firms to a control group of non-donating firms. The second model used structural equation modeling to test the mediating effects of stakeholder relationship intensity between firm and industry-level stakeholder orientations and performance on donating firms. In both tested models, our results indicate that instrumental theory hypothesis did not hold for our data. However, findings suggest that the market perceives stakeholder management as a firm cost, and that stakeholder relationship intensity can be explained by a one-dimension construct, measured by firm level indicators that describe the organizational context.
\end{abstract}

Keywords: instrumental stakeholder theory; firm performance; discretionary firm donation; multiple regression; structural equation modeling.

\section{INTRODUCTION}

Received in 05/16/2008; revised in 10/19/2008; accept in 04/12/2008.

Corresponding authors:

${ }^{\dagger}$ Analista Econômico

Endereço: Rua Guarará, 511, apt.

1506, Jardins, São Paulo - SP -

Brazil-CEP: 01425-001.

e-mail:luciano_rostagno@yahoo.com.br

Telefone: (11) 8557-1782

\author{
${ }^{¥}$ Professora Assistente da UNISINOS \\ Endereço: Rua Leblon, no.169, cs. \\ 106, Bairro Ipanema, Porto \\ Alegre - RS - Brazil \\ CEP: $91760-510$ \\ e-mail: ksoares@unisinos.br \\ Telefone: (51) 3209-9130
}

\author{
${ }^{¥}$ Professor Adjunto do Programa de \\ Pós-Graduação em Ciências \\ Contábeis da Universidade do Vale \\ do Rio dos Sinos - UNISINOS. \\ Endereço: Rua Leblon, no.169, cs. \\ 106, Bairro Ipanema, Porto Alegre - \\ RS - Brazil - CEP: 91760-510. \\ e-mail: rosoares@unisinos.br \\ Telefone: (51) 3209-9130
}

Editor's note: This paper was accepted by Alexsandro Broedel Lopes. 
takeholder management is often indicated as a crucial success factor. However, there is seldom empirical confirmation of this causal relation in Brazilian literature. Empirical studies abroad have concentrated mainly on the relationship between social performance and financial performance, which did not in 25 years produce converging results (ALEXANDER; BUCHHOLZ, 1978; ULLMANN, 1985; McGUIRE; SUNDGREN; SCHNEEWEIS, 1988; WADDOCK; GRAVES, 1997).

Understanding stakeholder management as one of the determining factors of the competitive e edge and superior performance finds support in the instrumental prospect of stakeholders proposed by Donaldson and Preston (1995). The authors claim that the effectiveness of stakeholder management is positively correlated to the conventional performance measures.

In this study the instrumental theory is empirically confirmed in the context of a turbulent environment (as is the Brazil case). Like other studies (ROBERTS, 1992; OGDEN; WATSON, 1999) stakeholder management of an organization is measured by a proxy formed by its donations to relevant stakeholder groups. Due to its notorious prominence for Brazilian firms, this study measures political and social donations.

Normally in empirical studies (BERMAN et al., 1999), stakeholder management is modeled as moderator of the relation between business strategy and performance. Nevertheless, Freeman (1999) points out that the results are not consistent, and suggests developing more sophisticated designs and measurements. Accordingly, two designs were used in the study: in the first, the direct effects of stakeholder management were checked when comparing donor and non-donor firms, with a view to the usual effects of the firm and industry; in the second, in a sample of donor firms, the mediating effect of the intensity of stakeholder management is found between the firm's strategic direction toward stakeholder management and performance, by modeling structural equations.

\section{THEORETICAL GROUNDS}

From the already existing contributions about the stakeholder theory, Donaldson and Preston (1995) divided it into three approaches: descriptive, instrumental and regulatory. They claim that the studies fit the descriptive theory when they describe or explain specific characteristics of corporate behavior toward stakeholders; instrumental when they seen to analyze the effect of the strategies and policies directed at stakeholders about corporate performance; and the regulatory theory "is used to interpret the role of the corporation, including identification of the moral or philosophical direction to administration and operation of companies" (DONALDSON; PRESTON, 1995, p.71).

The relation between the social and financial performance can be illustrated by applying the instrumental theory, since Jones (1995) writes that the studies that examined t his relation were not based on a reputable theory, and have "empirical data looking for a suitable theory" (ULLMANN, 1985, p. 555). Some studies are an exception (BERMAN et al., 1999; OGDEN; WATSON, 1999; LUK et al., 2005), since they empirically tested stakeholder approaches proposed by Donaldson and Preston (1995).

In the groundbreaking empirical work by Berman et al. (1999), the authors derived and tests two models in the context of the stakeholder theory: the first, called strategic stakeholder management reflects an instrumental approach; the second, called intrinsic commitment to stakeholders, is developed from a regulatory approach. Empirical tests withstood only the instrumental approach. 
Ogden and Watson (1999), in a case study of the water supply industry in England, found that the performance of the consumer services was significantly negative when correlated with the current profits, but positive when correlated with return measures for the shareholders.

When looking at the Chinese market - an economy in transition like Brazil -, Luk et al. (2005) focuses on the instrumental aspect of the stakeholder theory. They found a positive effect in the performance resulting in the combination of focus on consumer, competitors and employees, emphasizing that the combined effect of the three stakeholders was greater than individually.

Numerous studies relate social with financial performance, without considering the aspects discussed by Donaldson and Preston (1995), but the results are contradictory (COCHRAN; WOOD, 1984; DAVIDSON III; CHANDY; CROSS, 1987; DAVIDSON III; WORRELL, 1988; MCGUIRE; SUNDGREN; SCHNEEWEIS, 1988; GRIFFIN; MAHON, 1997; PRESTON; O’BANNON, 1997; PAVA; KRAUSZ, 1997; MOORE,2001; RUF et al., 2001). Authors Bromiley and Marcus (1989), for example, found a negative relationship between these two performances. Other authors reinforce the positive relationship between social and financial performance of firms, namely, Statman (2000), Tiras, Ruf and Brown (1998), Waddock and Graves (1997) and Preston and O'Bannon (1997).

Sundaram and Inpken (2004), when defending the proposal that the corporate objective must continue to maximize the value for the shareholder, criticize the papers that defend the multi-stakeholder service to obtain competitive edges (JONES, 1995; DONALDSON; PRESTON, 1995; ALTMAN, 1998). They point out that the link between a stakeholder and firm performance is widely refuted by the empirical results, as shown in the studies by Berman et al. (1999) and Agle, Mitchell and Sonnenfeld (1999), or are inconclusive, mentioning Griffin and Mahon (1997).

In Brazil studies on social responsibility date from the 1980s, but only at the end of the 1990s have studies on the stakeholder theory appeared in academic literature, mostly descriptive, without discussing the descriptive, regulatory and instrumental aspects defined by Donaldson and Preston (1995). Few relate the stakeholder theory, or some aspect of corporate social responsibility, to the firm's characteristics and its performance (CAMPOS, 2003; SOUZA; MARCON, 2003; ALBERTON, 2003).

In this study, when empirically testing the instrumental theory, the values donated to two primary stakeholders will be considered (CLARKSON, 1995): community and government. Their importance in corporate management in turbulent environments, such as the Brazilian context, justifies the choice of these two groups. The government (KEIM; BAYSINGER, 1988; FREEMAN, 1998; BUCHHOLZ; ROSENTHAL, 2004) and community (WADDOCK; GRAVES, 1997; ALTMAN, 1998; BERMAN et al., 1999) stakeholders are essential for strategic business administration. Most of the studies in the area used ordinal stakeholderrelated data, through indexes such as KLD (GRIFFIN; MAHON, 1997; GRAVES; WADDOCK, 1994). A few used values invested or donated to certain stakeholders, with emphasis on the studies by Ogden and Watson (1999) and Adams and Hardwick (1998).

The stakeholder theory also provides firmer grounds that lead firms to the stakeholderdriven attitude, since they manage implicit and explicit contracts among multiple stakeholders. If the managers administrate these contracts so that the firm improves its performance, this may infer an instrumental approach leading to donations (DONALDSON; PRESTON, 19995). Considering that there is a set of corporate and industrial characteristics that gives the firm a more favorable attitude to meeting stakeholder demands, the studies by Roberts (1992), and Adams and Hardwick (1998) have shown that variables such as property 
structure and size are essential when determining the level of donations made by firms, the firms being larger and with a more stakeholder-oriented diversified property structure.

\section{RESEARCH MODELS AND HYPOTHESIS}

This section discusses the two hypothetical models to empirical confirm the instrumental stakeholder theory. In line with the aforementioned arguments, the social and political donations are used as proxy of the intensity of the corporate relationship with two major stakeholders, the community and government.

Model I (Figure 1) shows the direct effects on performance of the strategic initiative in producing such political and social donations. Donations are modeled as a dummy variable, to compare the performance of donor firms with that of a control group, the non-donor firms. Due to non-modeling of the sum donated by the firms, model I does not verify the importance of the intensity of the relationship with the stakeholders, but the effects on the performance of a firm consider this relationship in its strategic actions.

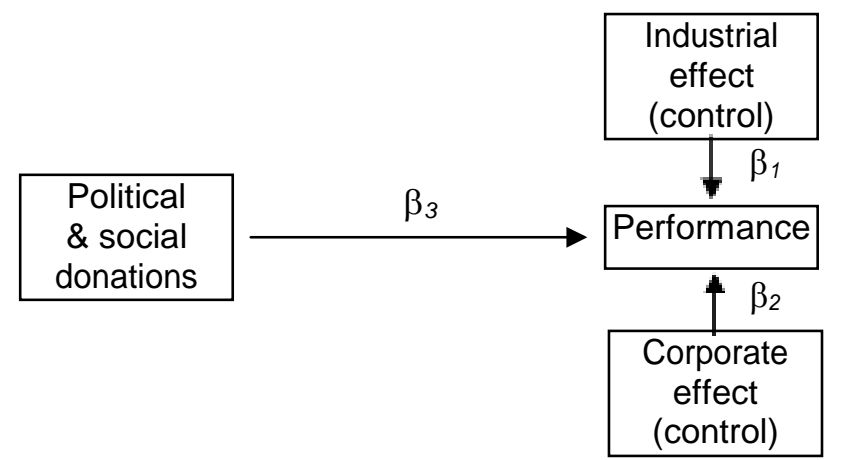

Figure 1: Modeling the direct effects of donations on performance

Model I provides controls for corporate and industrial effects, normally addressed as economic determinants of competitive edge and superior performance (RUMELT, 1991; ROQUEBERT; PHILLIPS; WESTFALL, 1996; McGAHAN; PORTER, 1997; HAWAWINI; SUBRAMANIAN; VERDIN, 2003). The effects of the industry capture the differences between the industrial structures that determine the average performance of the firms, such as defended by the Industrial Organization (PORTER, 1980; McGAHAN; PORTER, 1997). The corporate effects, however, measure the effectiveness in using higher resources and skills by the firms, along the ideas of Resource-Based View (RUMELT, 1991). In Brazil, studies showed that the effects of the industry and firm correspond from $2.1 \%$ to $7.1 \%$ and from $43 \%$ to $54 \%$, respectively, of the total variation found in corporate performance (BANDEIRA-DEMELLO; MARCON, 2004; BRITO; VASCONCELLOS, 2003). Therefore, hypothesis H1 is proposed, whose validation is obtained by the positive and significant coefficient for the Political and social donations path $\cong$ Performance:

$H_{1}$ : Meeting the social and political stakeholder demands has a positive influence on the firm's performance.

Model II checks the strategic importance of the intensity of the relationship with political and social stakeholders, considering that this intensity would measure the relation between the orientation to attend stakeholders and performance in donor firms. This 
orientation is understood to be a set of characteristics at the firm and industrial level that give the company a more favorable posture to giving such donations and meet stakeholder demands. An attempt is made to answer the following question: to what extent does the donated sum matter for firms more oriented to stakeholder service in order to increase their performance?

In model I two new constructs were added prior to donations: a) "Stakeholder orientation": refers to organizational characteristics associated with making donations, such as size and concentration of property; and b) "Industry-stakeholders relationship": refers to the industry-level characteristics, namely, differences between industrial plants regarding the relationship with political and social stakeholders, captured, for example, by the intensity of donations and proportion of donating firms in industry.

Model II must be understood as a path model with latent variables, not directly measured, but by observable indicators, as defined by structural equation modeling (HAIR et al., 1995; KLINE, 2005). Figure 2 explains the paths, indicators and coefficients to be estimated.

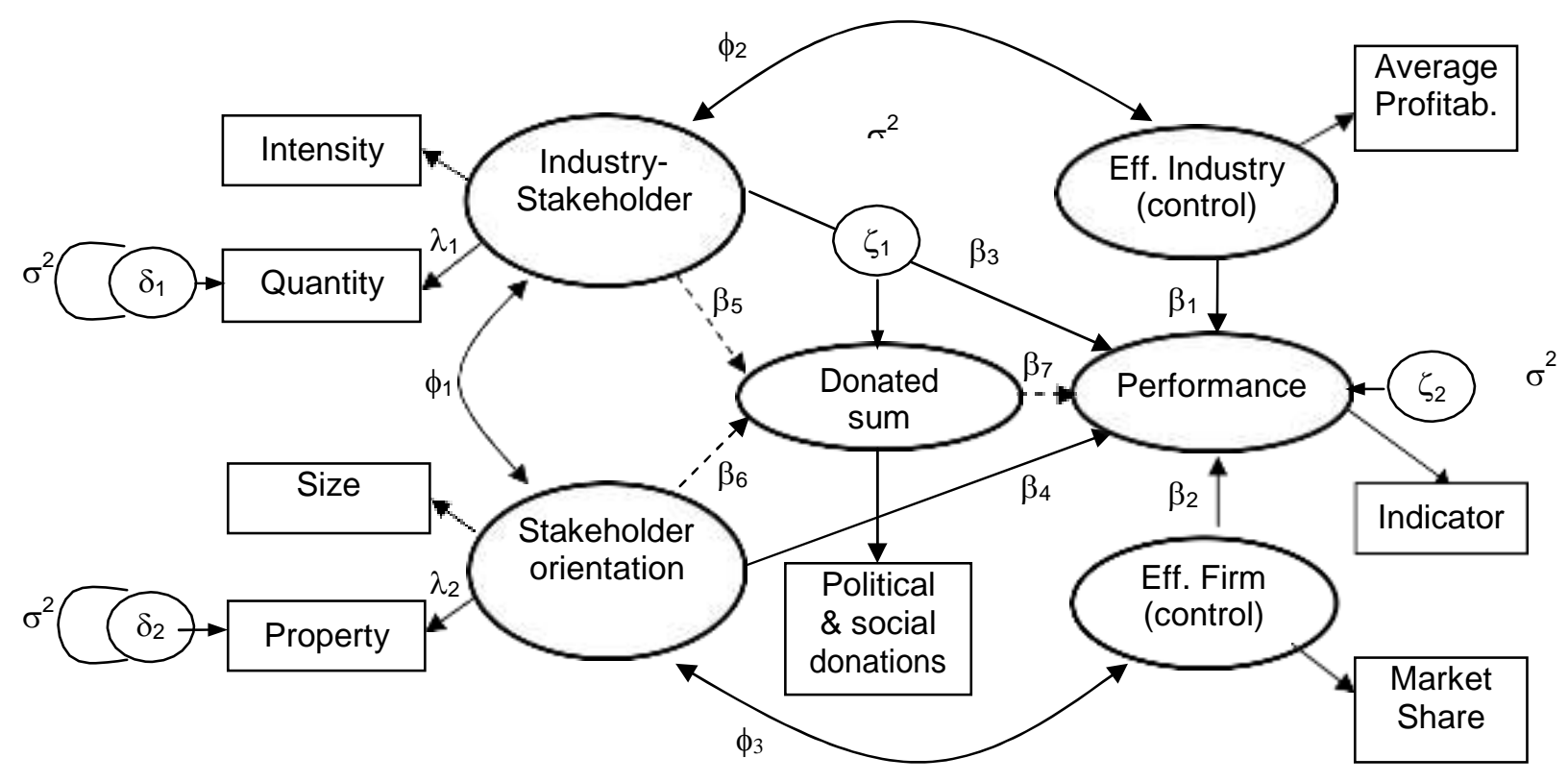

Figure 2: Modeling the mediating effects of the donations (path diagram)

In model II, the five constructs are represented by the ovals. The rectangles contain the indicators of each construct. The effect constructs of the firm, effects of the industry, donated sum and performance were measured by a single indicator $(\lambda=1)$, assuming that there is no measuring error $(\delta=0)$. Effects of the industry were measured by the average profitability of the sectors, the effects of the firm by the firm-related market-share, donations by the average sum donated to the political and social stakeholders and performance according to different measurements: ROE, ROA and Operational ROA. Moreover, there is no reason to restrict to zero the correlations between the two constructs preceding donations $\left(\phi_{1}\right)$, between the 
economic effects of the industry and industry-stakeholders relationship $\left(\phi_{2}\right)$ and between the effects of the firm and orientation to stakeholders $\left(\phi_{3}\right)$.

The two constructs preceding donations are measured by two indicators each. Firm size and share composition of the ownership measure the stakeholder orientation where larger firms with less share concentration tend to engender stakeholder relationships through donations. Intensity, which is the average sum donated by a certain industry. And quantity that reflects the relative number of donor firms in a sector, are indicators of the industrystakeholders relation construct. At the industry level, the nature of the activity of the sector mayencourage or not the strategic initiative of firms in attending stakeholders.

In Figure 2, the arrows without identified parameters reflect value 1 . The rest was estimated by the model. The design for testing mediating effects of the donations took the approach of Singh, Goolsby and Rhoads (1994) and Tippins and Sohi (2003) who propose testing alternative models and competitors. Two models are proposed in this test: a) without measuring the donations, which excludes the paths (dotted lines) represented by parameters $\beta_{5}, \beta_{6}, \beta_{7}$; and b) complete, with the inclusion of all paths represented in Figure 2 . In order to check the mediating effects, it is expected that, in addition to the significance of all coefficients involved, the model with mediation fits better than the one without mediation and that the coefficients $\beta_{3}$ and $\beta_{4}$ have a significant reduction when modeling the mediation of the donations, taking the second hypothesis:

$\mathrm{H}_{2}$ : The intensity of the political and social stakeholder relationship measured the relation between the firm's orientation to engender such relationships and its performance.

\section{DATA AND METHODS}

The data provide three sources: the ECONOMATICS base, where financial and accounting data were obtained from open corporations listed in the São Paulo stock exchange (Bovespa) (restricted to the sample); the Exame Guide to Corporate Good Citizenship [O Guia Exame de Boa Cidadania Corporativa ${ }^{1}$ ] which relates investments (donations) made by the firms to social projects, which acted as proxy in the community stakeholder relationship; and the official data of the firm donations to candidates or parties in the 1998 election campaign (1999-2002 campaign), proxy for the relationship with the government stakeholder.

The different social project modalities were added to the same variable, 'social donations', since in addition to statistical benefits, it reflects aspects relating to the same stakeholder - the community. Two different variables were added to a single variable donations. The sum of the political donations made in a single year with the annual average of the most importance to the former, but the political donations reflect and preserve their effects in the four year term, which justifies this decision. Adams and Hardwick (1998) claim that this junction also is justifiable by the fact that the quantity of political donations are not very representative in relation to the total donations of the firms and due to the difficulty in separating the effect of both donations ${ }^{2}$.

\footnotetext{
${ }^{1}$ The 2000 (first edition), 2001 and 2002 editions were used, relating the following social project modalities: third age support, child and adolescent support, support for people with special needs, community, culture, education, environment, partnership, health and volunteers.

${ }^{2}$ Adams \& Hardwick (1998) argue that it is hard to separate the effect of political from social donations since donations in the community can, for example, be made to please the political stakeholders to seek future benefits, in the same way that political donations can be made to a party that the firm believes will adopt good community practices.
}

BBR, Braz. Bus. Rev. (Eng. ed., Online),

Vitória, v. 5, n. 3, Art. 8, p. 275 - 293, sep.- dec. 2008

www.bbronline.com.br 
The instrumental stakeholder theory was verified in two stages. In the first, the coefficients of model I were estimated using the method of the minimum squared in a multiple regression (Equation 1).

PERF $_{i}=\beta_{o}+\beta_{1}$ INDUST $_{i}+\beta_{2}$ FIRM $_{i}+\beta_{3}$ DONATE $_{i}+\varepsilon_{i}$

Considering the inconsistency of the results found in earlier studies, various indicators were used for the performance to enable a comprehensive analysis of the effects of the stakeholder relationships, as mentioned by Griffin and Mahon (1997). Therefore, the coefficients of Equation 1 were estimated for each performance indicator used (Chart 1).

\begin{tabular}{|c|c|}
\hline Variable & Analytical and operational definitions \\
\hline $\begin{array}{l}\text { Firm } \\
\text { Performance } \\
(\text { PERF) }\end{array}$ & $\begin{array}{l}\text { Measured on basis of four variables: ROE, ROA, operational ROA and } \\
\text { P/VPA, considering the period 1999-2002. } \\
\text { ROE: Average net profit/net worth ratio. } \\
\text { ROA: Average net profit/total assets ratio. } \\
\text { Operational ROA: Average operating income / total assets ratio. } \\
\text { P/VPA: Average price-to-book, Price/Worth Value ratio. }\end{array}$ \\
\hline $\begin{array}{l}\text { Effects of } \\
\text { Industry } \\
\text { (INDUST) }\end{array}$ & $\begin{array}{l}\text { Definition of empirical study of Schmalensee (1985), Hansen \& Wernerfelt } \\
\text { (1989) and Stimpert \& Duhaime (1997). The representative measure of the } \\
\text { industry effect was the average ROE of the sector. } \\
\text { Sector ROE: Average of industry, ROEs that measure firm performance. }\end{array}$ \\
\hline $\begin{array}{l}\text { Effects } \\
\text { Firm } \\
\text { (FIRM) }\end{array}$ & $\begin{array}{l}\text { Fígura 1. Definition of the empirical study of Hansen \& Wernerfelt (1989), } \\
\text { quoted by Rumelt (1991), referring to the Schmalensee study (1985). The } \\
\text { representative measure of the firm effect was the Ln of the relative Market } \\
\text { Share. } \\
\text { Fígura 2. Relative Market share: Ratio between the firm market share and } \\
\text { industry concentration. } \\
\text { Fígura } 3 \text {. The firm market share is obtained by the ratio between the firm's } \\
\text { average net sales income and the net sales income of the industry, in the } \\
\text { period 1999-2002. } \\
\text { Fígura } 4 \text {. The concentration of the industry is obtained by adding the four } \\
\text { largest market shares in the sector, considering the average values for the } \\
\text { period 1999-2002. }\end{array}$ \\
\hline $\begin{array}{l}\text { Strategic } \\
\text { initiative } \\
\text { (DONATE) }\end{array}$ & $\begin{array}{l}\text { Dummy variable that compares donor firms (DONATE }=1 \text { ) with the reference } \\
\text { group: non-donor firms (DONATE }=0 \text { ). }\end{array}$ \\
\hline
\end{tabular}

Chart 1: Operating definition of the Model I variables

In the second stage, model II parameters were estimated directly from the sample, by interaction of the maximum likelihood, provided by module SEPATH of the statistical package STATISTICA. For stakeholder orientation constructs and industry-stakeholders 
relationship, loads to key indicators were fixed in 1 to set the scale and variance of the latent variables, and to contribute to identifying the model (HAIR et al. 1995).

As in Model I, parameters were estimated for the different performance indicators (Chart 1). And for each performance indicator, the hypothesis of mediation was analyzed, adding the variables described in Chart 2to model II.

\begin{tabular}{l|l}
\hline Variable & Analytical and operational definitions \\
\hline $\begin{array}{l}\text { Political } \\
\text { social } \\
\text { donations } \\
\text { (DONATION) }\end{array}$ & $\begin{array}{l}\text { LN of the sumo f political and social donations of each firm. } \\
\text { Political donation: total quantity donated in US\$ by each firm, to } \\
\text { candidates or political parties (irrespective of the party), in the 1998 } \\
\text { election (covering the period 1992-2002). } \\
\text { Social donation: annual average of donations in US\$ from each firm in } \\
\text { social projects, considering three periods, 2000-2002. The dollar } \\
\text { quotation at each year end was used to convert the values in R\$ to US \$. }\end{array}$ \\
\hline $\begin{array}{l}\text { Intensity } \\
\text { (INTENS) }\end{array}$ & $\begin{array}{l}\text { Square root of the ratio total donated/number of firms in industry, namely, } \\
\text { the square root of the quantity donated by each industry. }\end{array}$ \\
\hline $\begin{array}{l}\text { Quantity } \\
\text { (QUANT) }\end{array}$ & $\begin{array}{l}\text { Relative value of donor firms in industry, namely, the ratio number of } \\
\text { donor firms in industry/number of firms in industry. }\end{array}$ \\
\hline $\begin{array}{l}\text { Size } \\
\text { (SIZE) }\end{array}$ & $\begin{array}{l}\text { Ln of the average total assets of the firm, considering the period 1999- } \\
\text { 2002. }\end{array}$ \\
\hline $\begin{array}{l}\text { Property } \\
\text { (PROP) }\end{array}$ & $\begin{array}{l}\text { Average proportion of the total number of common shares belonging to } \\
\text { the main shareholder, in period 1999-2002, namely, the share composition } \\
\text { of the main shareholder. }\end{array}$ \\
\hline
\end{tabular}

Chart 2: Operating definition of variables (observed) added to Model II

Variables were transformed to obtain a normal univariate distribution. However, the hypothesis of normality in the Kolmogorov-Smirnov test was rejected from the performance indicator and QUANT variables. The INTENS variable was transformed to reduce kurtosis.

The following in the ECONOMATICS base were initially excluded from the sample: banks and financial institutions, due to the high degree of leverage; firms whose operating sector was not specified; firms that did not exist in 1998, since they did not participate in the election process; and firms that, although participants in the election process and social projects, were extinguished during the period under analysis. To improve the quality of the sample, deviation data were eliminated.

A sample of 339 firms in 16 sectors (rated according to the ECONOMATICS base) was the start for Model I. The influential findings for detecting outliers were analyzed on a single and multivariate basis for each regression, adopting the recommendations of Hair et al. (1995). The univariate analysis only of performance measures excluded 11 cases in which the values exceeded the limits of \pm 2.5 standard deviations, resulting in the final sample of 328 findings. For each regression, influential findings were analyzed on a multivariate basis by the Cook distance, which considers the overall analysis of deleted residual (studentized), and the relative distance of the rest of the findings (leverage). The sample resulting from each regression fulfilled the minimum criterion of 15 findings for each estimated coefficient (HAIR et al., 1995). Missing data were not a problem and the regressions used the pair-wise method to deal with missing findings.

In Model II, the initial sample was 102 donor firms. The analysis of the influential findings considered the intersection between the univariate analysis of the performance variables and the multivariate analysis based on the calculation of the Mahalanobis distance $\left(\mathrm{D}^{2}\right)$, considering all observable variables in Model II. Ten cases were excluded: three from BBR, Braz. Bus. Rev. (Eng. ed., Online), 
the Petrogas sector, two from the Steel/Metalworking sector and one in each of the Food, Electric Power, non-Metal Minerals, Textile and Transport and Service sectors, with the final sample of 92 findings in 13 sectors. After this analysis the Construction (no donor firms were found in this sector), non-Metal Minerals and Transport \& Service sectors were excluded.

\section{RESULTS}

The following items show the results of the study in accordance with the application of each of the two models: Model I and Model II, as response to the $\mathrm{H}_{1}$ and $\mathrm{H}_{2}$ hypotheses mentioned in section 3 , respectively.

\subsection{Empirical verification of hypothesis $\mathrm{H}_{1}$}

After removing the univariate outliers, the sector that most contributed (of the 16 under consideration) was Telecommunications (17\% of findings), and that with least frequency was found in the Mining sector (1.2\%). The Electric Energy and Steel/Metalworking sectors showed the highest number of donor firms and the non-Metal Minerals had the lowest. Table 1 shows descriptive measures of the variables used in Model I, as well as tests $t$ of the differences between donors and non-donors for the firm effect variables and performance indicators.

Table 1: Descriptive statistics and test $t$ of Model I variables

\begin{tabular}{|c|c|c|c|c|c|c|c|c|}
\hline Variable & Average & $\begin{array}{l}\text { Stand. } \\
\text { Dev. }\end{array}$ & Skewness & Kurtosis & $\begin{array}{l}\text { PONATE } \\
=0\end{array}$ & $\begin{array}{l}\text { DONATE } \\
=1\end{array}$ & $\mathrm{~T}$ & Sig. \\
\hline ROE & $-4.38 \%$ & 0.229 & -1.564 & 2.692 & $-6.850 \%$ & $1.004 \%$ & -2.881 & $0.004^{*}$ \\
\hline ROA & $-5.71 \%$ & 0.397 & -11.105 & $\begin{array}{l}151.88 \\
4\end{array}$ & $-9.170 \%$ & $2.002 \%$ & -3.488 & $0.001^{*}$ \\
\hline ROA_OP & $-2.12 \%$ & 0.201 & -1.559 & 4.152 & $-3.960 \%$ & $1.751 \%$ & -2.702 & $0.007^{*}$ \\
\hline P/VPA & 1.14 & 1.661 & 5.127 & 31.251 & 1.102 & 1.204 & -0.478 & 0.633 \\
\hline FIRM & -3.64 & 1.825 & -0.952 & 1.352 & -4.070 & -2.705 & -7.555 & $0.000^{*}$ \\
\hline INDUST & $-5.81 \%$ & 0.0725 & -1.554 & 7.126 & $-6.190 \%$ & $-4.940 \%$ & -1.445 & 0.150 \\
\hline
\end{tabular}

* Significant at $1 \%$

Significant differences are found between the averages of the financial and operating performance indicators, ROE, ROA and ROA_OP. The average of such indicators in the donor firms is significantly higher than those in the non-donors. The firm effect, represented by the natural logarithm of relative market share also showed the same behavior (the original values of the averages are $1.71 \%$ for those non-donors and $6.69 \%$ for donors). There was no difference in the performance measured by valorization of the actions by the market between both groups, and the donor and non-donor firms are present in industries whose average profitability is not very different.

The Model I coefficients were estimated for each performance indicator considered. Table 2 shows not only the constant $\beta_{o}$ but also the standard coefficients $\beta_{1}$ to $\beta_{3}$ and their significances, bivariate correlations of zero and partial for each variable.

Table 2: Estimates of Model I parameters 


\begin{tabular}{|c|c|c|c|c|c|}
\hline Ind. Var. & \begin{tabular}{l|l} 
Var. & ROE \\
\end{tabular} & $\mathrm{ROA}$ & ROA_OF & PVPA & \\
\hline Constant & $0.106^{*}$ & $0.074^{*}$ & $0.058^{\#}$ & $1.161^{*}$ & \\
\hline (sig.) & $(0.000)$ & $(0.001)$ & $(0.013)$ & $(0.000)$ & \\
\hline FIRM & $0.252^{*}$ & $0.271^{*}$ & 0.104 & $0.134^{\#}$ & \\
\hline (sig.; biv. & corr.;(0.000; & 0.300; (0.000; & 0.296; $(0.086$ & 0.106; $(0.038$ & 0.149 \\
\hline partial) & $0.245)$ & $0.263)$ & $0.101)$ & 0.129) & \\
\hline INDUST & $0.231^{*}$ & $0.182^{*}$ & $0.257^{*}$ & $.177^{*}$ & \\
\hline (sig.; (biv. & corr.; $; 0.000$ & $0.252 ;(0.000$ & $0.181 ;(0.000$ & $0.255 ;(0.004$ & 0.170 \\
\hline partial) & $0.242)$ & $0.191)$ & $0.257)$ & $0.179)$ & \\
\hline DONATE & 0.088 & 0.087 & 0.044 & 0.093 & \\
\hline (sig.; biv. & corr.;(0.132; & 0.196; (0.127; & $0.193 ;(0.471 ;$ & $0.099 ;(0.150$ & 0.147 \\
\hline partial) & $0.088)$ & 0.087) & $0.042)$ & 0.090) & \\
\hline $\mathrm{R}^{2}$ adjusted & $14.2 \%$ & $12.1 \%$ & $7.1 \%$ & $6.4 \%$ & \\
\hline $\mathrm{F}$ & $17.424^{*}$ & $15.428^{*}$ & $8.488^{*}$ & $5.835^{*}$ & \\
\hline$(\operatorname{sig})$ & $(0.000)$ & $(0.000)$ & $(0.000)$ & $(0.001)$ & \\
\hline DW & 1.965 & 2.033 & 2.038 & 1.887 & \\
\hline
\end{tabular}

* significant at $1 \% \quad$ \# significant at $5 \% \quad \mathrm{DW}=$ Durbin-Watson

All regressions produced significant models. The errors did not show serious signs of self-correlation, Durbin-Watson statistics were close to the desired value of 2.00. Nor did analysis of the residue reveal strong deviations from the standard, except for ROA (negative skewness) and PVPA (positive skewness)

Table 2 showed that the coefficient of the DONATE variable was not significant in any regression. Compared with the results in Table 1, it may be concluded that the differences in performance found between donor and non-donor firm groups is due primarily to an influence of the firm effect. Analysis of the bivariate and partial correlations shows that the single contribution of DONATE is insignificant when the FIRM and INDUST variables are in the model. This shows a presence of multicolinearity in which donating firms tend to have a larger relative market share (tolerance indicators between the two variables were below 0.90 for all models). Based on such evidences, hypothesis $\mathrm{H}_{1}$ cannot in any way be accepted.

Mention should be given to some specific results. In no regression, the dependent variables explain more than $15 \%$ of the performance, which requires better specification of the model. Except for the performance measured by PVPA and ROA_OP, the firm effects were more important than the industry effects.

\subsection{Empirical verification of hypothesis $\mathrm{H}_{2}$}

For the empirical verification of model 2, the final sample of 92 donor firms in 13 sectors showed the averages of the variables, described in Table 3. The smallest donation registered was US\$ 2,752.29 (Hercules, Steel/Metalworking) and the highest US\$ 4,900,469.70 (Vale do Rio Doce, Mining), calculating an average donation of US\$ $537,038.25$.

Table 3: Averages of donor firs per sector (sample from model II) 


\begin{tabular}{|c|c|c|c|c|c|c|c|}
\hline Sector & $\begin{array}{l}\text { No. } \\
\text { finding } \\
\mathrm{s}\end{array}$ & $\begin{array}{l}\text { Intensity } \\
\text { (US\$) }\end{array}$ & $\begin{array}{l}\text { Quantity } \\
(\%)\end{array}$ & $\begin{array}{l}\text { ROE } \\
(\%)\end{array}$ & $\begin{array}{l}\text { ROA } \\
(\%)\end{array}$ & $\begin{array}{l}\text { ROA_OP } \\
(\%)\end{array}$ & $\begin{array}{l}\text { PVPA } \\
(\%)\end{array}$ \\
\hline Food\&Beverage & 6 & $114,469.73$ & 28.00 & 10.60 & 4.21 & 5.20 & 1.480 \\
\hline Commerce & 3 & $193,318.38$ & 21.43 & $\begin{array}{l}- \\
20.40\end{array}$ & -8.70 & -1.40 & 1.650 \\
\hline $\begin{array}{l}\text { Electro- } \\
\text { electronics }\end{array}$ & o & 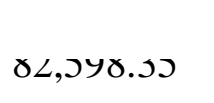 & $4 \angle .00$ & 10.02 & 3.48 & 2.31 & 1.475 \\
\hline Electric energy & 15 & $146,276.47$ & 44.44 & -1.70 & -2.90 & 0.19 & 0.777 \\
\hline Industrial Mach. & 3 & $91,168.28$ & 25.00 & 14.81 & 6.00 & 6.43 & 1.333 \\
\hline x $x: \ldots$ & $?$ & $\begin{array}{l}1,270,660 \\
00\end{array}$ & $10 . \mathrm{UU}$ & 8.45 & 5.74 & 11.10 & 1.377 \\
\hline Pulp\&Paper & 6 & $657,553.71$ & 60.00 & 8.43 & 4.55 & 12.80 & 0.929 \\
\hline Petrogas & 1 & $879,250.64$ & 44.44 & ND & ND & ND & ND \\
\hline Chemicals & 13 & $162,747.56$ & 40.63 & -8.60 & 3.31 & 2.56 & 1.195 \\
\hline Steel\&Metal. & 14 & $257,309.06$ & 39.02 & 5.31 & 3.64 & 2.88 & 0.564 \\
\hline $\begin{array}{l}\text { Telecommunicati } \\
\text { ons }\end{array}$ & 11 & Yग,गY4.YY & 10.04 & 3.73 & 2.52 & 3.25 & 1.552 \\
\hline Textile & 7 & 45,492 & 25.00 & 5.66 & 3.48 & 5.54 & 0.591 \\
\hline Vehicles \& Parts & 4 & $116,762.89$ & 18.18 & 12.90 & 3.86 & 5.56 & 1.733 \\
\hline All sectors & 92 & $221,950.60$ & 36.82 & 3.00 & 2.59 & 3.79 & 1.13 \\
\hline
\end{tabular}

Table 4 shows the correlation matrix (Pearson) of the observable variables used in the path diagram of Figure 2 and which acted as input for directly estimating the model II parameters, using the structural equation modeling.

Table 4: Correlation matrix of the observable variables of model II

\begin{tabular}{|c|c|c|c|c|c|c|c|c|c|c|c|}
\hline $\begin{array}{l}\text { Variable } \\
\mathrm{s}\end{array}$ & $\begin{array}{l}\text { Quan } \\
\mathrm{t}\end{array}$ & Intens & Size & Prop & $\begin{array}{l}\text { Donatio } \\
\text { n }\end{array}$ & ndust & Firm & ROE & $\begin{array}{l}\text { RO } \\
\mathrm{A}\end{array}$ & ROAop & $\begin{array}{l}\text { PVP } \\
\text { A }\end{array}$ \\
\hline Quant & 1 & & & & & & & & & & \\
\hline Intent & $0.77^{*}$ & 1 & & & & & & & & & \\
\hline Size & 0.17 & 0.18 & 1 & & & & & & & & \\
\hline Prop & 0.10 & 0.01 & $0.28^{*}$ & 1 & & & & & & & \\
\hline $\begin{array}{l}\text { Donatio } \\
n\end{array}$ & 0.10 & $0.21^{\#}$ & $0.50^{*}$ & $-0.25^{\#}$ & \# 1 & & & & & & \\
\hline Indust & $0.39^{*}$ & $0.54^{*}$ & 0.10 & 0.05 & 0.17 & 1 & & & & & \\
\hline Firm & 0.05 & 0.08 & $0.64^{*}$ & $-0.35^{*}$ & $0.40^{*}$ & 0.05 & 1 & & & & \\
\hline ROE & -0.01 & 0.06 & 0.10 & -0.17 & 0.18 & 0.14 & 0.17 & 1 & & & \\
\hline ROA & 0.02 & 0.19 & -0.13 & -0.09 & 0.13 & $\begin{array}{l}0.21 \\
\#\end{array}$ & 0.03 & $0.81^{*}$ & 1 & & \\
\hline ROAop & 0.11 & 0.19 & 0.02 & 0.02 & 0.12 & 0.17 & 0.13 & $0.64^{*}$ & $0.78^{*}$ & 1 & \\
\hline PVPA & -0.14 & -0.04 & 0.12 & 0.02 & 0.20 & 0.20 & 0.16 & $0.25^{\#}$ & 0.19 & 0.17 & 1 \\
\hline
\end{tabular}

$*$ significant at $1 \% \quad$ \# significant at $5 \%$

The use of correlations instead of covariance provides estimated parameters comparable to each other and to coefficients $\beta$ of model I. The sample size used to estimate the parameters should be mentioned. Although smaller than the ideal size (150-200 findings) for estimating 
with ML (HAIR et al., 1995) and than the minimum 100 (LOEHLIN, 1992; KLINE, 2005), the sample of 92 findings in model II meets some prerequisites: it is larger than the minimum permitted of 50 findings for ML estimation (HAIR et al., 1995); the relations of the number of case per estimable parameter of 7.67 and 5.47 for the models with and without mediation, respectively, are larger than the minimum 5.00 (BENTLER; CHOU, 1987; HAIR et al., 1995); and it has a good number of freedom ratings (KLINE, 2005). Nevertheless, the number of findings fails to reach the suggested 15 cases per observable variable (13.14 and 11.50, for models without and with mediation, respectively).

Table 5 shows the coefficients estimated for all models used to test hypothesis $\mathrm{H}_{2}$. Eight variations from model II were estimated, with and without the effect of mediation of the latent variable 'donated sum', for each of the four performance indicators.

Table 5: Estimated coefficients for structural model

\begin{tabular}{|c|c|c|c|c|c|c|c|c|}
\hline \multirow[b]{2}{*}{ Relations } & \multicolumn{2}{|l|}{ ROE } & \multicolumn{2}{|l|}{ ROA } & \multicolumn{2}{|c|}{ ROA_OP } & \multicolumn{2}{|l|}{ PVPA } \\
\hline & With & $\begin{array}{l}\text { Withou } \\
\mathrm{t}\end{array}$ & With & $\begin{array}{l}\text { Withou } \\
\mathrm{t}\end{array}$ & With & $\begin{array}{l}\text { Witho } \\
\text { ut }\end{array}$ & With & $\begin{array}{l}\text { Witho } \\
\text { ut }\end{array}$ \\
\hline Ef. Industry 徊Performance $\left(\beta_{1}\right)$ & 0.148 & 0.159 & 0.146 & 0.163 & 0.093 & 0.101 & $0.309^{*}$ & U.5 \\
\hline Ef. of Firm $\sim$ Performance $\left(\beta_{2}\right)$ & 0.174 & 0.194 & 0.189 & 0.217 & 0.202 & 0.215 & 0.126 & 0.148 \\
\hline 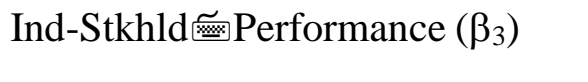 & -0.041 & -0.030 & 0.119 & 0.133 & 0.141 & 0.147 & $0.240^{*}$ & 0.227 \\
\hline $\begin{array}{l}\text { Stkhld Orient. } \underset{\text { Performance }}{\left(\beta_{4}\right)}\end{array}$ & -0.097 & -0.043 & $\begin{array}{l}0.381 \\
*\end{array}$ & $0.304^{*}$ & -0.190 & $\begin{array}{l}- \\
0.157\end{array}$ & -0.024 & 0.036 \\
\hline Indust-Stkhld $\simeq$ Sum Donated $\left(\beta_{5}\right)$ & 0.120 & n.a. & 0.120 & n.a. & 0.120 & n.a. & 0.120 & n.a. \\
\hline 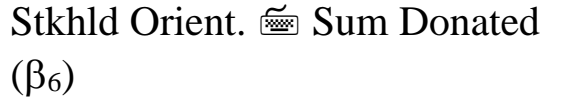 & $0.481^{*}$ & n.a. & $\begin{array}{l}0.481 \\
*\end{array}$ & n.a. & $0.481^{*}$ & n.a. & $0.481^{*}$ & n.a. \\
\hline $\begin{array}{l}\text { Sum Donated } \cong \text { Performance } \\
\left(\beta_{7}\right)\end{array}$ & 0.138 & n.a. & 0.195 & n.a. & 0.087 & n.a. & -0.024 & n.a. \\
\hline Sig. of Chi-Squared & 0.657 & 0.223 & 0.576 & 0.190 & 0.724 & 0.791 & 0.557 & 0.594 \\
\hline Steiger-Lind RMSEA & 0.000 & 0.038 & 0.000 & 0.048 & 0.000 & 0.000 & 0.000 & 0.000 \\
\hline Joreskog GFI & 0.953 & 0.931 & 0.950 & 0.926 & 0.956 & 0.966 & 0.951 & 0.959 \\
\hline Joreskog AGFI & 0.916 & 0.896 & 0.909 & 0.889 & 0.921 & 0.940 & 0.912 & 0.929 \\
\hline
\end{tabular}

* significant at $5 \% \quad$ n.a. $=$ not applicable

The models showed 20 and 24 freedom ratings, with and without mediation effect, respectively. The model is recursive and interaction did not result in any absurd parameter, being characterized by over-identified models. Fit indexes presented prove satisfactory (some with excellent fit, with very low RMSEA indices). However, the expected penalization is found by AGFI due to the lack of parsimony (few relationship restrictions between variables) ${ }^{3}$. Before interpreting the estimated coefficients, the premises of normality and the measuring model quality are analyzed. The multivariate kurtosis measurements, provided by SEPATH did not reveal serious problems of normality (relativized Mardia-based Kappa coefficients showed values close to the desired value of 1.00 fore all model II variations). No normalized residue was outside the $195 \%$ confidence limit.

\footnotetext{
${ }^{3}$ Indicators for possible re-specifications of the model provided by SEPATH (Lagrange Multiplier) did not suggest modifications.
}

BBR, Braz. Bus. Rev. (Eng. ed., Online),

Vitória, v. 5, n. 3, Art. 8, p. 275 - 293, sep.- dec. 2008

www.bbronline.com.br 
The eight variations of model II showed for the two latent variables an industrystakeholder relationship and stakeholder orientation, significant loadings for their indicators equal to $0.770(\mathrm{p}=.000)$ for $\lambda_{1}$ and $-0.277(\mathrm{p}=.004)$ for $\lambda_{2}$, at $1 \%$. The extracted variance and reliability were calculated at 0.80 and 0.88 , respectively for the industry-stakeholder relationships construct, and at 0.54 and 0.64 , for stakeholder orientation, indicating acceptable values (HAIR et al. 1995).

Table 5 showed few significant coefficients ${ }^{4}$. The models without mediation of the sum donated showed significant coefficients only in two cases - ROA and PVPA - which revealed the following pattern: in the performance measured by ROA, specific firm characteristics seem to have a more significant influence on the performance than industry-level characteristics; and, in the performance measured by PVPA, the industry characteristics are those than matter, evidencing that in Brazil the investors, when selecting their investments, prefer the sectors more than the individual firms. Ogden and Watson (1999) found that the firms that invested in the client-stakeholder increased the market value of their shares.

On one hand this implies that the more a firm orientation to engendering donations (large firms and not very concentrated share composition), the less its financial performance tends to be measured by $\operatorname{ROA}\left(\beta_{4}=-.304\right)$. And the larger the relative market share (hypothetically reflecting more efficiency in using its resources and skills), the greater its $\operatorname{ROA}\left(\beta_{2}=.217\right)$.

On the other hand, while the attraction level of the industry in which a certain firm operates positively influences the valorization of its shares in the market $\left(\beta_{1}=.321\right)$, the market seems to negatively assess firms that are in industries related more closely to their stakeholders $\left(\beta_{3}=-.227\right)^{5}$. It may be inferred that possible causes of this difference are the nature of certain industries, which impel their firms to donate more heavily and in a higher number than others, and which is perceived by the market as a risk or form of compensation of these firms for damages caused to the general public or to that fact that they are more subject to government regulations.

The introduction of mediation of the donated sum construct did not provide statistically coefficients other than zero. Only the stakeholder orientation $\underline{\underline{w}}$ Donated Sum path $\left(\beta_{6}=.481\right)$ proved significant for all performance measurements. This indicates that a 'profile' can be identified of a firm more likely to engender such donations.

However, the 'profile', or stakeholder orientation, without mediation, showed a negative influence $\left(\beta_{4}=-.381\right)$ in the financial performance (ROA). This result shows firms to be apparently inefficient that tend to be more stakeholder-oriented, permitting interference in interpreting the donated sum as an expense, which gives no return. One of the reasons for such a result can be the variable considered for donation. When analyzing five variables that can capture the posture of the stakeholder oriented firm, Berman et al.(1999) found that only two of them, employees and quality of the product, directly affect the performance of the firm, also measured by ROA, but the community variable did not show a statistically significant impact.

In the same ROA model with mediation, although finding a positive relationship $\left(\beta_{7}=.195\right)$ between Donated Sum $\simeq$ Performance, mediation of the donated sum explains only 9.4\% $\left(\beta_{6} * \beta_{7}=.094\right)$ of the variation in performance. The apparent incoherence between the signs of $\beta_{4}$ and $\beta_{6} * \beta_{7}$ can be explained by the lower value of the coefficients.

\footnotetext{
${ }^{4}$ Significance tests for paths introduced into the model with mediation and tests of coefficients of the control variables were unilateral due to the positive directionality, expected for such relationships.

${ }^{5}$ This can also be found in the PVPA model, with mediation.
} 
Based on such evidence, hypothesis $\mathrm{H}_{2}$ cannot be acceptable. Lastly, the modeled correlations, except for $\phi_{1}$, present significant values and with the expected sign for all variations in model II. This means that more attractive industries are those that have a closer relationship with their stakeholders $\left(\phi_{2}=0.533\right)$ and firms that have a stronger stakeholder orientation generally have larger market shares $\left(\phi_{3}=0.639\right)$. The sign of correlation $\phi_{2}$ seems to contradict the results obtained by coefficients $\beta_{1}$ and $\beta_{3}$, in the model with PVPA mediation; and the sign correlation $\phi_{3}$, in turn, with those of coefficients $\beta_{2}$ and $\beta_{4}$, in the model without ROA mediation. Such contradictions can be explained by the fact that $\beta_{1}$ and $\beta_{2}$, in their own models, have low values or by the existence of multicolinearity between the control and exogenous latent variables.

\section{DISCUSSION}

The objective of this paper was not to measure the causal relation between social performance and performance as in the studies of McGuire, Sundgren and Schneeweis (1988), Preston and O'Bannon (1997) and Ruf et al. (2001), for example. The purpose was to analyze the competitive effect between stakeholder orientation and performance, and for this reason the variables were measured for the same period. Designed from the stakeholder theory, the hypotheses that the intensity of the relationship with political and social stakeholders measured the ratio between firm orientation and its performance and that attending to these stakeholders positive influences the firm's performance, were tested first using a regression model and later a structural equation model.

In this study the interaction between strategy and stakeholder relationship was not modeled, as generally used in other designs, either for mediation or moderation, (BERMAN et $a l ., 1999)$. To check the instrumental theory, it was assumed that donor firms are companies whose donation is part of the strategy, to the extent that it is undertake to improve performance. The firms used the controls to isolate, within the effects of the overall strategy, how donation effects influence different performance measurements (DONALDSON e PRESTON, 1995, p.67).

Despite model I, donor firms had financial and operating performance indicators higher than the non-donors, and it was not possible to infer that they can explain the donation, since the donation variable coefficient was not significant in the regressions undertaken, which leads to the conclusion that the differences in the performance are due first to the size effect of the firm, and thereby hypothesis 1 is not acceptable.

By introducing mediation of the donated sum construct in model II only the stakeholder

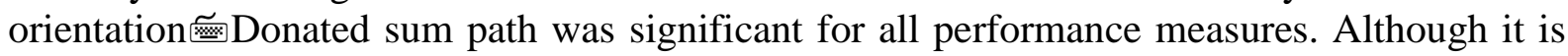
indicative that a 'profile' can be identified of a firm more likely to engender such donations, the 'profile' or stakeholder orientation without mediation was a negative influence on the financial performance (ROA). This result shows an apparent inefficiency of firms that tend to be more oriented toward the stakeholder relationship, suggesting the interpretation of the donated sum as a cost, without producing return. Based on such evidence, hypothesis $\mathrm{H}_{2}$ is unacceptable.

Considering that the dependent variables in no regression explain more than $15 \%$ of the performance, this leads to a need for better specification of the model, but, except for PVPA and ROA_OP, the firm effects were more important than the industry effects.

In general, the tested models explain very little about the variation of performance in this type of environment, which is a mainstream challenge for the strategy and finance area. 


\section{CONCLUSIONS}

In this study, the instrumental theory, as provided by Donaldson e Preston (1995), found no empirical evidence in turbulent environments. Nevertheless, although its hypotheses are not accepted, it will not be refuted. Possible solutions undergo better specification of the theory for this type of environment and the consequent re-specification of the model, alternative measuring of the relationship and intensity, or even incorporation other major stakeholder groups.

The results found must be interpreted with caution, for two main reasons. a) Principally in structural equation modeling, the smaller sample, together with low values of some coefficients, can make the coefficients unstable, which would explain the contradictions between the signs of some coefficients and between the signs of coefficients and correlations. A small sample diminishes the power of significance tests of estimated parameters and increases the sampling error, making it harder to reject the null hypothesis (KLINE, 2005), but, although smaller than the ideal size, the sample is larger than the minimum permissible and list of number of cases per parameter. b) The presence of various insignificant coefficients tends to inflate the model's fit measurements based on the chi-square (FORNEL \& LARCKER, 1981).

Another limitation regarding the proxy used for investments in the community and regarding information made available. When considering the social projects as proxy of the community relationship, not all operations of the firms are being considered that comprise the sample, but a certain project or set of actions taken by them (VERGARA \& BRANCO, 2001). Social projects can be significant social contributions, but only represent one of the dimensions of social responsibility with regard to the relationship with the community (COELHO, 2004). While the social projects represented only one part of the community stakeholder relationship, it is possible that in many cases the lack of systematized information in the firms about their social projects ends up by underestimating value of donations, with no mention in the Exame Guide, and even projects referenced but with ND value (not declared).

For future studies, a design may be considered with moderation of the stakeholder relationship, in the strategy and performance relation, and the use of multivariate performance measures that, as suggested by Chakravarthy (1986), could capture the return for multiple stakeholders. Nonetheless, the inclusion of more parameters in model II would increase the problems of the limited sample and could incur the risk of testing hypotheses of a regulatory rather than instrument theory of the stakeholders. An examination of the causal relation between stakeholder orientation and performance, inclusion of orientation for other stakeholders, the use of other measures can also be dismemberments for new studies. Industry and stakeholder orientation are valid concepts to provide the donated sum, but the validity can be enhanced, seeking other indicators that describe the concept, in addition to the size and structure of property.

Due to the few empirical studies available and complexity of the relationship between the stakeholder theory and performance of the firms, this study, like so many others, does not exhaust the subject, but hopefully it has contributed to a reflection on the need for empirical studies in the light of the stakeholder theory not only in developed countries but in emerging economies and turbulent environments like Brazil.

\section{REFERENCES}

ADAMS, M.; \& HARDWICK, P. An analysis of corporate donations: United Kingdom evidence. Journal of Management Studies, 35(5), 641-654, 1998. 
AGLE, B. R.; MITCHELL, R. K. \& SONNENFELD, J. A. Who matters to CEOs? An investigation of stakeholders attributes and salience, corporate performance, and CEO values. Academy of Management Journal, 42(5), 507-525, 1999.

ALBERTON, A. Meio ambiente e desempenho econômico-financeiro: o impacto da ISO 14001 nas empresas brasileiras. 2003. 307 p. Thesis (Doctorate in Production Engineering) Post-graduate Production Engineering Program (PPGEP), Universidade Federal de Santa Catarina (UFSC), Florianópolis.

ALEXANDER, G. J. \& BUCCHOLZ, R. A. Corporate social responsibility and stock market performance. Academy of Management Journal, 21(3), 479-486, 1978.

ALTMAN, B. W. Corporate community relations in the 1990s: a study in transformation.

Business and Society, 37(2), 221-227, 1998.

BANDEIRA-DE-MELLO, R.; MARCON, R.., 2004. A Mensuração Multivariada da Performance e Suas Componentes de Variância: Uma Análise dos Efeitos do Ano, Indústria e Firma no Contexto Brasileiro. In: ENANPAD, 28., 2004, Curitiba. Anais... Rio de Janeiro: ANPAD, 2004. 16 p.

BENTLER, P. \& CHOU, C. Practical issues in structural modeling. Sociological Methods and Research, 16(1), p. 78-117, 1987.

BERMAN, S. L.; WICKS, A. C.; KOTHA, S. \& JONES, T. M. Does stakeholder orientation matter? The relationship between stakeholder management models and firm financial performance. Academy of Management Journal, 42(5), p. 488-506, 1999.

BRITO, L. A. L. \& VASCONCELOS, F. C. Firm performance in an extremely turbulent environment: year, industry and firm effects. In: ENANPAD, 27, 2003, Atibaia. Anais... Rio de Janeiro: ANPAD, 2003.

BROMILEY, P. \& MARCUS, A. The deterrent to dubious corporate behavior: profitability, probability and safety recalls. Strategic Management Journal, 10(3), 233-250, 1989.

BUCHHOLZ, R. \& ROSENTHAL, S. Stakeholder theory and public policy: how governments matter. Journal of Business Ethics, 51(2), 143-153, 2004.

CHAKRAVARTHY, B. Measuring strategic performance. Strategic Management Journal, 7(5), 437-458, 1986.

CLARKSON, M. B. E. A stakeholder framework for analyzing and evaluating corporate social performance. Academy of Management Review, 20(1), 92-117, 1995.

COCHRAN, P. L. \& WOOD, R. Corporate social responsibility and financial performance. Academy of Management Journal, 27(1), 42-56, 1984.

COELHO, M. Q. Indicadores de performance para projetos sociais: a perspectiva dos stakeholders. In: ENANPAD, 28., 2004, Curitiba. Anais... Rio de Janeiro: ANPAD, 2004. 16 p.

DAVIDSON III, W.N.; CHANDY, P.R. \& CROSS, M. Large losses, risk management and stock returns in the Airline Industry. Journal of Risk and Insurance, 54(1), 162-172, 1987. 
DAVIDSON III, W. N. \& WORRELL, D. L. The impact of announcements of corporate illegalities on shareholder returns. Academy of Management Journal, 31(1), p. 195-200, 1988.

DONALDSON, T. \& PRESTON, L. E.. The stakeholder theory of the corporation: concepts, evidence and implications. Academy of Management Review, 20(1), 65-91, 1995.

FORNEL, C. \& LARCKER, D. Evaluating structural equation models with unobservable variables and measurement error. Journal of Marketing Research, 18(1), 39-50, 1981.

FREEMAN, R. Edward. A stakeholder theory of the modern corporation. In: M. B. E. Clarkson (ed.), The corporations and its stakeholders: classic and contemporary readings. Toronto: University of Toronto Press, 1998. 125-138.

FREEMAN, R. E. Strategic management: a stakeholder approach. Boston: Pitman, 1984. FREEMAN, R. Edward. Divergent stakeholder theory. Academy of Management Review, 24(2), 233-236, 1999.

GRAVES, S. B. \& WADDOCK, S. A. Institutional owners and corporate social performance. Academy of Management Journal, 37(4), 1035-1046, 1994.

GRIFFIN, J. J. \& MAHON, J. F. The corporate social performance and corporate financial performance debate. Business \& Society, 36(1), 5-31, 1997.

HAIR, J; ANDERSON, R.; TATHAM, R. \& BLACK, W. Multivariate data analysis. $5^{\text {th }}$ ed. New Jersey, 1995.

HAMBRICK, D. C. Operationalizing the concept of business-level strategy in research. Academy of Management Review, 5(4), 567-575, 1980.

HANSEN, G. S. \& WERNERFELT, B. Determinants of firm performance: the relative importance of economics and organizational factors. Strategic Management Journal, 10(5), 339-411, 1989.

HAWAWINI, G.; SUBRAMANIAN, V. \& VERDIN, P. Is performance driven by industry or firm-specific factors? A new look at the evidence. Strategic Management Journal, 24(1), 1-16, 2003.

JONES, T. M. Instrumental stakeholder theory: a synthesis of ethics and economics. Academy of Management Review, 20(2), 404-437, 1995.

KEIM, Gerald D. \& BAYSINGER, Barry D. The efficacy of business political activity: competitive considerations in a principal-agent context. Journal of Management, 14(2), 163$180,1988$.

KLINE, R. Principles and practice of structural equation modeling. $2^{\text {nd }}$ ed. New York: The Guilford Press, 2005.

LOEHLIN, J. Latent variables models: an introduction to factor, path, and structural analysis. $2^{\text {nd }}$ ed., Hillsdale: Lawrence Erlbaum, 1992.

LUK, C.; YAU, O.H.M.; TSE, A.C.B.; SIN, L.Y.M. \& CHOW, R.P.M. Stakeholder orientation and business performance: the case of service companies in China. Journal of International Marketing, 13(1), 89-110, 2005. 
McGAHAN, A. M. \& PORTER, M. E. How much does industry matter, really? Strategic Management Journal, 18(Summer Special Issue), 15-30, 1997.

McGUIRE, J.B.; SUNDGREN, A. \& SCHNEEWEIS, T. Corporate social responsibility and firm financial performance. Academy of Management Journal, 31(4), 854-872, 1988.

MOORE, G. Corporate social and financial performance: an investigation in the U.K. supermarket industry. Journal of Business Ethics, 34(3/4), 299-315, 2001.

OGDEN, S. \& WATSON, R. Corporate performance and stakeholder management: balancing shareholder and customer interests in the U.K. privatized water industry. Academy of Management Journal, 42(5), 526-538, 1999.

PAVA, M. L. \& KRAUSZ, J. Criteria for evaluating the legitimacy of corporate social responsibility. Journal of Business Ethics, 16(3), 337-347, 1997.

PHILLIPS, R.; FREEMAN, R.E. \& WICKS, A. C. What stakeholder theory is not. Business Ethics Quarterly, 13(4), 479-502, 2003.

PORTER, M. Competitive strategy. New York: Free Press, 1980.

PRESTON, L. E. \& O'BANNON, D. P. The corporate social-financial relationship: typology and analysis. Business \& Society, 36(4), 419-429, 1997.

REVISTA EXAME. Guia Exame de boa cidadania corporativa. São Paulo: Editora Abril, 728 ed., 2000(119 p.); 754 ed., 2001(210 p.); 781 ed., 2002 (210p.).

ROBERTS, Robin W. Determinants of corporate social responsibility disclosure: an application of stakeholder theory. Accounting Organizations and Society, 17(6), 595-612, 1992.

ROQUEBERT, J. A.; PHILLIPS, R. L. \& WESTFALL, P. A. Markets vs. management: What drives profitability? Strategic Management Journal, 17(6), 653-664, 1996.

RUF, B.M.; MURALIDHAR, K.; BROWN, R.M.; JANNEY, J.J. \& PAUL, K. An empirical investigation of the relationship between change in corporate social performance and financial performance: a stakeholder theory perspective. Journal of Business Ethics, 32(2), 143-156, 2001.

RUMELT, R. P. How much does industry matter? Strategic Management Journal, 12(3), 167-185, 1991.

SCHMALENSEE, R. Do markets differ much? The American Economic Review, 75(3), 341-351, 1985.

SINGH, J.; GOOLSBY, J. \& RHOADS, G. Behavioral and psychological consequences of boundary spanning burnout for customer service representatives. Journal of Marketing Research, 31(4), 558-569, 1994.

SOUZA, M. J. B. \& MARCON, R. Responsabilidade Social Corporativa, Vantagem Competitiva e Desempenho Financeiro. In: Third Iberoamerican Academy of Management International Conference, 3., 2003, São Paulo. Proceedings... São Paulo: Iberoamerican Academy of Management, 2003.

STATMAN, M. Socially responsible mutual funds. Financial Analyst Journal, 56(3), 30-39, 2000. 
STIMPERT, J. L. \& DUHAIME, I. Seeing the big picture: the influence of industry, diversification, and business strategy on performance. Academy of Management Journal, 40(3), 560-583, 1997.

SUNDARAM, A. K. \& INPKEN, A. C. The corporate objective revisited. Organization science, 15(3), 350-363, 2004.

TIPPINS, M. \& SOHI, R. IT competency and firm performance: Is organizational learning a missing link? Strategic Management Journal, 24(8), 745-761, 2003.

TIRAS, S.; RUF, B. \& BROWN, R. M. The relation between stakeholders' implicit claims and firm value. In: www.ssrn.com, Sep. 1998.

ULLMANN, A. A. Data in search of a theory: a critical examination of the relationships among social disclosure, and economic performance of U.S. firms. Academy of Management Review, 10(3), 540-557, 1985.

VERGARA, S. C. \& BRANCO, P. D. Empresa humanizada: A organização necessária e possível. Revista de Administração de Empresas, 41(2), 20-30, 2001.

WADDOCK, S. A. \& GRAVES, S. B. The corporate social performance-financial performance link. Strategic Management Journal, 18(4), 303-319, 1997. 